\title{
The Body As Weapon: Bobby Sands and the Republican Hunger Strikes.
}

\author{
by Chris Yuill \\ Robert Gordon University \\ Sociological Research Online, Volume 12, Issue 2, \\ < http://wnw.socresonline.org.uk/12/2/yuill.htm/> \\ doi:10.5153/sro. 1348
}

Received: 6 Oct 2005 Accepted: 9 May 2006 Published: 30 Mar 2007

\begin{abstract}
The 1981 Hunger Strike marked an important point in the Northern Ireland conflict, shifting its focus away from city streets and country lanes into the H-Block prison. Here republican prisoners used their embodiment to resist and fight back at attempts to recast them as criminals as opposed to the soldiers they perceived themselves to be. Given the centrality of the body and embodiment in the prison struggle this paper will theorise the 'body-as-weapon' as a modality of resistance. This will begin by interrogating key themes within the sociology of the body before discussing and dismissing an alternative explanation of the Hunger Strike: the actions of the hunger strikers standing in the traditions of heroic Gaelic myths and Catholic martyrdom. Finally, drawing from the sociology of the body, I will then proceed to discuss how the body and embodiment deployed in this manner can be effective, concentrating on how the 'body-asweapon': (i) acts as a resource for minority political groups; (ii) destabilises notions of the body in modernity and related to that point (iii) engages in a 'hidden' impulse of modernity, that of self-sacrifice.
\end{abstract}

\section{Keywords: Embodiment, Conflict, Modernity, Northern Ireland, Resistance}

\section{Introduction}

“I was thinking today about the hunger strike. People say a lot about the body, but don't trust it."

Bobby Sands, 1981.

1.1 The 1981 Hunger Strike in Northern Ireland resulted in Bobby Sands and nine other republican prisoners losing their lives. The Hunger Strike, and a series of other prison based protest beforehand, came about as both a response to changes in British prison policy and the wider Northern Irish political situation. Key to this phase of 'The Troubles' was the use that the prisoners made of their bodies and embodied activity as a way of resisting and fighting back against the prison warders and the British state. In effect their bodies became weapons in this conflict. This has parallels with contemporary instances where minority political groups use their bodies and embodied activity as part of a wider struggle with groups who possess greater political, technological and military resources. Obviously, one can draw attention to September $11^{\text {th }}$ in New York, the 7/7 tube and bus bombings in London and asylum seekers in Glasgow stitching their mouths, though these events will not be discussed here.

1.2 This paper will explore the Hunger Strike to theorise the 'body-as-weapon', and how, in this case, the body and embodied activity were effective in realising certain goals of a minority political group. Though there have been some quite insightful studies of this event, such as anthropologist Feldman (1991), who first used the term 'body-as-weapon', there is little from the perspective of sociology of the body. It is from this standpoint that the theoretical basis of my argument will proceed ${ }^{[1]}$.

1.3 Opening with an interrogation of key themes within the sociology of the body attention will then turn to looking at issues of the body and embodiment within the British/ Irish conflict. Here, it will demonstrated that the body has long acted as a significant resource, whether symbolically or materially within the conflict. Before moving onto a fuller discussion of the 'body-as-weapon', one competing explanation of the Hunger Strike, that of it being inspired by romantic Gaelic mythology and traditions of Catholic martyrdom, will be critiqued. Finally, the 'body as weapon' will be theorised, mainly in context of the Hunger Strike, but also offering possibilities for wider theoretical deployment. The main points developed here will be how the 'body-as-weapon' (i) acts as a resource for minority political groups; (ii) destabilises notions of the body in 
modernity and related to that point (iii) engages in a 'hidden' impulse of modernity, that of self-sacrifice.

\section{Sociology of the body}

2.1 As stated above, this paper takes its theoretical orientation from the sociology of the body, and from this analyses the body and embodiment within violent political conflict. Before doing so, it will be useful to foreground my discussion with a summary and review of sociology of the body. The body and embodiment are now firmly part of the sociological imagination with a whole sub-discipline (for a fuller account see Shilling, 2005) generating a variety of empirical and theoretical insights into the relationship between the body and society. In many respects a sociological concern with the body is comparatively recent beginning in the late 1970's and early 1980's (Turner 2003: 272, Yuill and Lewis, 2003). One can, however, detect in the classical canon an appreciation or awareness of the body in the works of Marx (Yuill 2005), Durkheim (Shilling, 1997, 2001) and Weber (Turner, 1993), the body here being, in Shilling's (1993) words, an 'absent presence'. Due to sociology having to stake out its own distinctive realm of study the body was put aside with emphasis falling on the non-corporeal rational social actor (Burkitt, 1999). This is evident in one of Durkheim's (1968: 1) reflections on the genesis of the discipline: 'sociology would have no subject matter exclusively its own, and its domain would be confused with that of biology and psychology.'

2.2 In many ways, the history of sociology has mirrored the Cartesian mind-body dualism (and all the attendant problems and complications that poses) inhered in western intellectual traditions. This dualist position would be challenged though, by developments, within both society and the academy, that would bring issues of the body into sharp relief for sociologists, (Shilling, 2005: 2-5). These trends included the awareness of the body's importance within consumerism (Featherstone, 1991); feminist challenges to malestream sociology (Grosz, 1994); Foucaldian concerns of governmentality; and the dividing lines between nature and society (Haraway, 1991). One could also add medical sociology where, as Williams and Bendelow (1998a: 22) appositely remark, that when studying, 'pain and suffering, sickness, disability and death the body has been an implicit, if not explicit, theme.' There has though, been insufficient attention paid to the body in violent political conflict, a theme this paper will tackle.

2.3 In terms of theoretically addressing the body Turner's (1984) The Body and Society stands as a landmark development. Turner advances a theory that focuses on the 'downstream' effects of somatic society and it imprinting on the body societal patterns and restraints, though lately he (Tuner, 1996) has tried to introduce an 'upstream' understanding of how bodies are experienced phenomenologically, and can be active in creating and (re)producing society. This development chimes with a wider move within sociology of the body. Here we see a shift towards seeing the body not as a passive object, receiving of society, but as an agentic subject, transforming of society. This avoids reproducing a dualism where a structural focus is on what happens to body implying a separation from the mind. Williams and Bendelow (1998a: 208, their emphasis) usefully summarise this way of seeing the body as, 'an active, expressive, 'mindful' form of embodiment that serves not only as the existential basis of culture and self, but also of social institutions and society generally.' Other sociologists such as Crossley (1995), have drawn on the phenomenology of the French philosopher Merleau-Ponty (2002 [1945]) to assist in theoretically grounding this departure, seeking to access the Leib, lived experience of the body, centring on the experiential aspects of embodiment. It is this active embodiment that will be highlighted during the discussion of the 'body-asweapon'.

2.4 Other theoretical influences emerge from the work of Goffman (1968) and Bourdieu (1984) where the body acts as a form of social resource, or as part of a project, where the body is worked upon to meet certain needs and ends Shilling (1993). Goffman's micro-sociology builds on the everyday dramas of identity management centred on the body (Williams and Bendelow, 1998). The body, adorned, posturing and presented in specific ways allows for social acceptance and it is with the body the everyday social world is encountered and negotiated. For Bourdieu the body offers a physical capital that can unlock and access social and cultural capital (Shilling, 1993).

2.5 Even though not explicitly concentrating on the body, the work of Elias (2000) also possesses insights for sociology of the body (Shilling, 1993: 150). Central to Elias' sociology is the dynamic and relational 'civilising process' whereby, among other interrelated processes, the body becomes individualised, rationalised and socialised. Thus, the further along the civilising curve a society is, the more the body becomes 'worked upon'. Here people are required to conform to ever increasing societal and internal impulses that seek to restrain, control and refine aspects of biological function and embodied practice, with bodies acquiring an individual as opposed to group identity. One example of this restraint on the body, as expounded by Inglis (2002), is that of the disposal and status of excrement. In modernity such matters become a hidden and potentially shameful activity. Given the prominent use of excrement in the hunger strike this will be developed at greater length.

2.6 Despite this variety of ontological and epistemological differences and convergences, as indicated 
above, within the sociology of the body, Shilling (2005: 199) concludes that it offers a 'multi-dimensional medium for the constitution of society.'

\section{The body in the Irish Conflict}

3.1 The body and embodiment have been important in many of the conflicts between Britain and Ireland. Historically, there is the placing of the wild Irish body 'beyond the pale', where a defensive and symbolic barrier around the south of Dublin separated the 'civilised' English settlers from the 'barbarous' Irish. Again, historically, there have also been a movement of bodies following the depopulation of Ireland that occurred in and around the Great Famine. The colonial relationship at this time between Britain and Ireland manifested itself in the starving bodies of the Irish peasantry. The failure of the potato crop is often cited as being the cause of this tragedy. But as de Paor (1970) points out there was enough food in Ireland to avert the thousands of deaths. Tragically however, the needs of the Irish people were subordinated to the profit making needs of the Anglo-lrish land owning elites. In the recent and ongoing 'Troubles we have seen various demographic convulsions and mass movements of bodies being displaced, whether voluntary or involuntary, to live in areas dominated by their co-religionists. While rejecting the notions of a deepening apartheid in Northern Ireland, and questioning the basis of the data by which religio-spatial segregation is measured, Anderson and Shuttleworth (1998) conclude that there have been significant increases in the sectarian geography of Northern Ireland.

3.2 Within Republicanism the idea of the 'sacrificed' or 'martyred' body plays an important symbolic role. The flawed, and overly ambitious, 1916 uprising owed perhaps more to the Romanticism of leading republican Pearse, than to good solid revolutionary tactics. The consequent executions of the ringleaders turned popular support towards the Republicans and away from the British state, with the martyred ringleaders gaining an almost quasi-religious status after their deaths (Allen, 1990). There is also, of course, Pearse's (in)famous invocation and exaltation of the martyred body he provided in his oration at the funeral of O'Donnovan Rossa:

“...but the fools, the fools, the fools! They have left us our Fenian dead, and while Ireland holds these graves, Ireland unfree shall never be at peace."

(quoted in Coogan, 2002: 30)

3.3 Following on from the last point, funerals, and their subsequent mass mobilisation of ordinary people to attend them, also indicate another important use of the body within the Republican tradition. Thousands of people could be expected to attend the funeral of an 'ordinary' IRA volunteer at the height of the Troubles, with tens of thousands attending the funeral of Bobby Sands (Toolis, 1995). From a Durkheimian perspective we can witness such events as providing a renewal and reinvigoration of the emotional commitment - an instance of emotional effervescence - to the Republican cause.

3.4 It is just not within Republican/ Nationalist traditions that the body plays an important role. For Unionists, particularly working class loyalists, the heavy losses suffered by the $36^{\text {th }}$ Ulster Division during the Battle of the Somme in World War One carries a great deal of symbolic, cultural and political importance. This historical event is often invoked by loyalist paramilitaries to justify and legitimate present day activities. Recruited out of the Carson's anti-Irish Home Rule Ulster Volunteer Force (UVF) the $36^{\text {th }}$ Ulster Regiment were the embodiment of Ulster Protestant pro-British Unionism. On the first three days of the Somme German machine gun fire inflicted 5500 casualties with nearly 3000 fatalities (Graham \& Shirlow, 2002: 882). This particular blood sacrifice, 'has become central to the imaginative narratives of memory that underpins loyalist self-identification (Graham and Shirlow, 2002: 888). Murals in working class loyalist areas often make much use of this bodily sacrifice, constituting one of the main historical images deployed in loyalist street-art (Rolston, 1991). Again, the 'sacrificed body' plays a role in the current conflict but this time within the narratives of Unionism and Loyalism.

3.5 The main use of the body though, which I wish to concentrate on in this paper, is the use of the body within the various prison struggles that existed in Northern Ireland from the mid-seventies to the early eighties. Many commentators (for example, Clarke, 1987; English, 2003) make mention of how the 'battlefield' of the Troubles shifted away from urban streets and quiet country lanes to the prisons; particularly that of Long Kesh. Throughout the late seventies and early eighties the British government attempted to redefine the status of republican prisoners, seeking to recast then as criminals instead of the prisoners-of-war they perceived themselves to be. This involved revoking the special status the prisoners previously held, which allowed them to effectively organise large parts of prison lives for themselves and, crucially, wear their own clothes. Part of the British government's crimilisation process entailed the wearing of a prison uniform, or 'monkey suit' as the prisoners referred to them. This shift in policy, which saw a symbolic reordering of the prisoners' bodies from soldier to criminal, was the cause of the prison conflict. The prisoners resisted by refusing to wear the new uniform and declining food. The consequences of which, 
were to see prisoners clothed only in blankets, starving themselves to death and living in cells filled with excrement. Many prisoners also reported being physically abused by prison warders.

3.6 I shall now turn more squarely to the role of the body in 'the reality of life in a seven-foot concrete box with a Bible, mattress, three blankets and a cell-mate for company' (Beresford, 1994: 27). In his writings, Sands frequently highlights the body, making constant reference to the pained and brutalised bodies of himself and other prisoners. We read of bodies 'aching', 'burning', 'freezing', 'shivering', 'gasping', 'smelling', becoming 'physically wrecked' and 'degenerating'. There is also much reference to enduring the 'crawling' and 'pestering' presence of parasitic insects. The ultimate result of this privation saw bodies becoming 'a living corpse', which was 'useless', 'tattered', and 'battered bloody'. As the preceding summary indicates much of the experience is one of pain and unremitting hardship. There are also many descriptions of the waste products of the body adding to the privation, for example:

\begin{abstract}
'Naked, I rose and crossed the cell floor through the shadows to the corner and crossed the cell floor through the shadows to the corner to urinate. It was deadly cold. The stench rose to remind me of my situation and the floor was damp and gooey in places. Piles of rubbish lay about the cell and in the dimness dark, eerie figures screamed at me from the surrounding, dirty, mutilated walls. The stench of excreta was heavy and lingering. I lifted the small water container from amongst rubbish and challenged an early morning drink in a vain effort to remove the foul taste in my throat. God it was cold.'
\end{abstract}

(Sands, 2001: 25-6)

3.8 Other prisoners too were highly aware of their bodies and the changes that were happening to them:

\begin{abstract}
"Two things which unsettled me stick in my mind, though. Firstly I became aware of the smell from my body. Initially, because of the circumstances, I thought it might be my imagination playing tricks. I was reticent about mentioning it to the other hunger strikers, but I did and I was relieved to discover that some of them too sensed a smell from their own bodies. It was the smell of the body wasting itself, the smell you sometimes sense when paying respect to the dead."
\end{abstract}

(Leo Green quoted in Campbell et al. 1994: 119)

\title{
Myths and Martyrs
}

4.1 Before dealing with a fuller explication of the body as weapon one important other explanation of the hunger strike has to be interrogated and dismissed. This line of thought argues that the Hunger Strike fits into a tradition within Irish culture that emphasises and valorises bodily denial and starvation. Within Republican circles, and among some writers, such as O'Malley (1990) and Sweeney (1993), it is suggested that this is so. One tradition that is referred to is Brehon law. Arising in pre-Christian times this custom involved an aggrieved person forgoing food, while situated near the person with whom they were in dispute. If the aggrieved person died then it was the responsibility of the other party, who, in turn, would then have to face the problems of compensating the now deceased's family, and risk the 'magical consequences' of living in a 'polluted state' (Sweeney, 1993: 422, Beresford, 1994). As Sweeney (1993: 422) notes this 'was a tactic employed by the powerless against the powerful.'

4.2 There are some fundamental problems with this particular explanation. Firstly, it presupposes a seamless primordial ethnie stretching back into time forming an uninterrupted link between the distant past and the immediate present. This echoes the debate that exists in the study of national identity. This debate turns on whether the nation (and related ideas of culture and history) is basically bound up in the project of modernity (for example, Anderson, 1991) or whether there exists a pre-modern ethnic navel (for example, Smith, 1986). As Beresford observes there are few examples of self-starvation between the middle-ages and the late 1800's. Historian Hutton (1993: 284) also warns that in 'In the search for 'pagan survivials' the historian encounters ...enormous problems.' This is mainly due to a total lack of evidence that the custom in question has survived intact given the 'year zero' influence of Christianity, the historical arrival of which effectively removed more pagan myths than incorporated them. Hutton (1994) also advises on being wary of Romantic or Victorian attempts to revive ancient pagan myths and customs. Often such attempts recast such myths in the light of their times, effectively divorcing the myth from any historical accuracy.

4.3 The influence of Catholicism may also play a role in the Hunger Strike. Catholicism has undoubtedly been a strong player within Irish culture. T. Inglis (2003) points to how Catholicism has played a uniquely pivotal role in Irish history and culture, not only dominating the religious field, but also strongly influencing other fields as well: the Catholic habitus of self-denial and self-deprecation, for example, being important for social acceptance within Irish society. For O'Malley (1990) the martyr tradition in Catholicism was an 
important factor in the Hunger Strike. Many of the murals painted during the time of the Hunger Strike also witnessed testimony to this putative relationship of Catholicism with the Hunger Strike. Murals often depicted the hunger strikers alongside angels or Christ, some portraying the hunger strikers in religious or quasi-religious representations (Rolston, 1991). It too would be tempting to also assume that there is a direct proximal influence of Catholicism. Feldman (1991) disputes this and notes in his interviews with the hunger strikers their reasons for embarking on the hunger strike were secular not sacral. A reading also of some of the written output by surviving hunger strikers, particularly that of McKeown (2001, and also Campbell et al., 1994), also supports this view that religion's role was not strong.

4.4 The role of Catholic traditions and the pre-Christian Brehon laws is not then to act as a direct proximal influence, but rather as a resource that could be deployed to add further legitimacy and political expediency. By adopting the imagery of Catholicism, or appealing to ancient Irish tradition, the hunger strikers could further emplace themselves as oppressed people fighting for higher ideals and as contemporary examples of heroic Irish culture (Coulter, 1999).

\section{The 'body-as-weapon'}

5.1 So how can we define or put forward the concept of the 'body-as-weapon'? Feldman (1991) in his anthropological account of the hunger strike explored the body as weapon in relation to Nietzsche, Spinoza and Foucault. The body here is 'a cumulative effect of exchanges between agonistic forces' (Feldman, 1991: 177). In true Foucauldian style Feldman sees the coexistence of oppression and resistance taking place on the prisoners' bodies. Whenever there was an act of violence carried on the body by the prison staff there was a counter-defilement by the prisoners to attempt a reversal of power (Feldman, 1991: 178-9). Therefore, the body becomes a weapon, the means by which the prisoners strike back at the authorities, or as a former hunger striker reported, 'from the moment we hit the H-Block we had used our bodies as a protest weapon' (Feldman, 1991: 179). There is much merit in Feldman's observation here, but his comments on the 'body as weapon' are fairly brief and will benefit from expansion by drawing on the insights from the sociology of the body. This section then will further theoretically explore the hunger strike. Much of the analysis will pertain to the 'body-as-weapon' in this context, but comments will be made that could be expanded to other instances of the body and embodiment being used in this manner.

\section{(i) The 'body-as-weapon' - resource}

5.2 The body is one of the few resources to which oppressed groups can have access. In the case of the Hunger Strikers this is highly evident. One of the main methods of resistance for the Republican movement during the recent Troubles had been armed resistance, and, as prisoners, Sands and his comrades obviously had no access to that military resource. The Republicans also lacked political resources for a number of reasons. Historically, the parliamentary road to Irish independence had been unsuccessful with the in-built prejudices and interests of the mainly Conservative, and Unionist, British establishment actively undermining democratic solutions (Dangerfield, 1997). During the genesis of the 'The Troubles' democratic and parliamentary solutions were equally unobtainable (McCann, 1980).

5.3 Denied of other resources and modalities of resistance the number of options for oppressed groups can be limited. The body then can emerge as being the one of the few resources that can be mobilised. It is a resource in the phenomenological sense that the body, and embodiment, are how we are in the world (Merleau-Ponty, 2002). Humans both 'are' and 'have' a body and as Shilling (1993: 5) observes the body can be a project, one where the body can be reconfigured and developed in accordance with someone's desires and objectives:

'This involves a practical recognition of the significance of bodies; both as personal resources and as social symbols which give off messages about a person's self-identity. In this context, bodies become malleable entities which can be shaped and honed by the vigilance and hard work of their owners.'

5.4 Shilling here is referring mainly to embodied projects pertaining to consumerism and health. The point of the agentic malleability of the body is equally applicable here, with the Hunger Strikers reframing their bodies as a modality of resistance in order to reaffirm their self identity as republican soldiers, rather than as the common criminals the British state were attempting to recast them. The vigilance and hard work involved in this project included the denial of food, going without clothes and living in wretched polluted conditions.

5.5 Even though I am drawing attention to the agentic aspects of the body here, it must be stated that this does not imply a complete tabula rasa, where agency can be exercised unhindered. This embodied agency exists within a historically derived present where certain parameters and barriers are already defined. It is within these parameters that this agency is practiced. Further to this point though, such parameters and 
barriers should not be read as being immutable and incapable of change. The agent of change here is embodiment exerting an 'upstream' influence on society. The potency it has in doing so is discussed next.

\section{(ii) The 'body-as-weapon' - destabilising discourses of embodiment in modernity}

5.6 Attention now turns to asserting how the 'body-as-weapon' can challenge sources of domination and oppressive social structures. This lies with the 'body-as-weapon's' capacity to destabilise notions and discourses of the body and embodiment in modernity. Here everyday assumptions of embodied practices, postures and presentations that form secure ontologies of the body are challenged, inverted and interrogated. There is a rupturing of conceptualisations of the body that can pose challenges for how others feel about their own embodiment. In Goffman's (1968) dramaturgical approach, for example, a certain corporeal stability is constructed through interaction with others. A body that does not match, or confronts, this expectation is stigmatised and shunned (Shilling, 1999). The body in modernity is also an important site of identity (Giddens, 1991), social distinction (Bourdieu, 1984) and a place of the rehearsal and performance of consumerism (Featherstone, 1991). And crucially, in light of the status of bodily waste in the Hunger Strike, embodiment and the body are also involved in the civilising process. It is this particular civilised process discourse of embodiment that I wish to concentrate on as it provides a clear example of how the 'body as weapon' can be destabilising of such discourses.

5.7 This destabilising of civilised embodiment is evident in the use of faecal matter during the Hunger Strike and the preceding Dirty Protest. In the Dirty Protest the prisoners' access to toilets and to buckets with which to slop out was denied on the grounds that the prisoners refused to wear prison uniforms (O'Malley, 1990). Very quickly the cells became filled with the putrid stench of urine and faeces. Blanketman Laurence McKeown (2001: 72) conveys something of the experience:

"Soon the cells began to stink and dust gathered. Denied access to the toilet we used the chamber pots. As these went on for days without the being emptied we poured the urine out the side of the door and threw the excreta out the windows. The screws' reaction was to pour very powerful undiluted disinfectant under the doors, making the occupants of the cells violently sick. Some had to smash the windows for ventilation."

5.8 Sands (2001: 50-1) recorded something similar:

"An unwashed body, naked and wrecked with muscular pain, squatting in a corner, in a den of disease, amid piles of putrefying rubbish, forced to defecate on the ground where the excreta would lie and the smell would mingle with the already sickening evil stench of urine and decaying waste food.'

5.9 Inglis (2002: 207) makes the interesting point that the 'faecal realm' is consistently ignored by mainstream scholarship. On one hand, the control, concealment and containment of excrement is profoundly important to the rational rhythms of modernity (Inglis and Holmes, 2000), while on the other, symbolic uses of excrement are important in rhetorics of abuse concerning minority groups and the maintenance of colonial power over subject people (Inglis, 2002).

5.10 In the first case, modernity has striven ever more to make sure that random defecatory rhythms become both set into strict timeframes and the action itself is removed from public view. Following Elias (1995), Inglis \& Holmes (2000: 226) note that the shift into modernity has seen a shift from 'faecal visibility to faecal invisibility. That is to say, from defecation occurring in primarily public locales, to mostly happening in locations deemed to be "private." All matters pertaining to the faecal have been shut away, concealed in the toilet or water closet, the 'unpleasant' odours concealed by a multitude of 'sweet smelling' chemical odours and the immediacy of defecation deferred and controlled to what are deemed appropriate times. In short, for the modern mind (and nose) defecation, and its products, are banished to a hidden private regulated realm.

5.11 In the second case, Inglis (2002) draws our attention to the symbolic aspects of faeces and how they play a role in denoting the superiority of dominant colonising groups over subaltern colonised groups. On one level this operates on the street insult level, terming some one a 'Paki shit', for example, on another level it claims that those who are deemed to be a subject group practice a less hygienic and effective toiletry habitus. The abodes they live in becoming 'dens of dirt' and less clean or sanitary than they might have been otherwise - essentially, 'faecal matters are always inherently political in character' (Inglis, 2002: 207 , emphasis in original).

5.12 Both these strands of thought do have instructive implications for the study of the use of the body in the prison wars. The case so far, mainly following Elias, is that modernity has consigned excrement into a strict concealed toiletry habitus, any challenge to which is a possible challenge to modernity and to wider 
perceptions of living in a 'civilised society'. Additionally, claiming that someone is shit and does not understand how to correctly dispose of their shit is a way in which to delineate power structure. In both the Dirty Protest, in particular, and also in the Hunger Strike the disposal of faeces and the act of defecation took place in such a way that inverted, to some extent, the accepted civilised norms and toiletry habitus associated with modernity.

\section{(iii) The 'body-as-weapon' - Self-sacrifice and modernity}

5.13 During the Hunger Strike as Mulcahy (1995) notes much was made in the popular press of the frail skeletal bodies of Sands and his comrades. The body and the demise of the body were central to both this media focus and public support of the hunger strikers. This indicates another aspect of the 'body-asweapon': the deliberate and wilful taking of one's life in an act of self-sacrifice. All the Republican prisoners volunteered for the hunger strike in full cognition that this would entail their own death (Beresford, 1994; Sands, 1998). Soldiers in conventional armies, on the other hand, attempt to maximise their survival, the vast majority of who never enter into combat situations intending to die. May this not be an extension of the previous section, where the destabilisation of embodied discourses was explored as a reason for the potency of the 'body-as-weapon'? This is certainly so with many bodily discourses in contemporary society dedicated to maximising youth and the longevity of life. As Bauman (1992), for example, indicates the dedication that so many people have to health and fitness regimes is an attempt to deny the facticity of that one certainty all bodies face and that is death. Or perhaps self-sacrifice belongs to cultures and societies outside modernity? However, self-sacrifice in this context, I believe, speaks to a 'hidden' impulse in modernity, especially when it comes to political struggle.

5.14 O'Neil (1984) makes an interesting observation on this point regarding self-sacrifice vis-à-vis modernity. Far from self-sacrifice being an act associated solely with the ancient world, either to encourage a deity to grant a full harvest or as a way to unit a given community for example, it plays a strong, if under theorised and under researched role, within modern society. There are many examples of self-sacrifice whether with the Japanese kamikaze pilots in WWII, the heroic individualism of European Romanticism or the sacrifices made by individuals during the French and American revolutions that were the harbingers of modernity. People in these events were willing to die for the modernist vision of liberty, equality and fraternity.

5.15 As Williams (1998b, 2001) has argued modernity should not be seen purely as a clinical rational scientific event, but one where emotions should be granted the same status as the rational. Some instructive ideas are to be found in the debate concerning what Collins (1998) refers to as the 'underground wing' of Durkheim's sociology. Here, the emotional side of Durkheim's writings are explored to indicate that our rational scientific world requires an emotional 'fiery furnace' to maintain and re-invigorate itself. For Shilling (1997:206) Durkheim's depiction of our inner life being 'like a double centre of gravity', the homo duplex, is an important moment in truly understanding the sensual and affective fundamentals to Durkheim's work. Here antagonistic binary opposites give rise to social and individual behaviour. One pole of this relationship is the strain between the passionate impulses of the irrational and the cool passionless rational. The other pole is a sees the friction between the individual and all that is beyond the individual in the world of the social. These opposite, combinative forces that dwell within us lead to the 'painful character' of 'human nature', where there is no victory of one of these forces without inflicting pain upon the other. This has leads to two instructive points for the case being argued here. Firstly, as Shilling notes, following Simmel (1950), this leads to the individual having to reach beyond themselves, controlling and dampening egoistic irrational impulses to accommodate to social norms and to make society possible. Here, society becomes internalised and the emotional miasma is channelled into supporting prevailing patterns of sociality. Thus, these 'contract' emotions are at the basis of human action, guiding, prompting and providing the energy to act socially. Secondly, Durkheim reminds us with his version of the homo duplex that emotions have not been utterly liquidated by the onslaught of passionless, rational modernity and that even though the order of the day maybe a rational menu, so to speak, emotions are still very much present in providing the 'fuel' for rational activity. As Durkheim stated:

"Even to the secular mind, duty, the moral imperative, is something august and sacred; and reason, the indispensable ally of moral activity, naturally inspires similar feelings"

(Durkheim, 1973 [1914]: 159)

5.16 The actions of the Hunger Strikers could be seen as an example where both emotions and rationality work in tandem and are embodied in their actions. Throughout the work of Sands (and the other hunger strikers) a passionate commitment to their republican ideals is highly apparent:

"'Tiocfaidh ar la!" I screamed out the door. One of the boys down the wing began to sing. A Nation Once Again resounded and echoed from behind every door and everyone joined in to 
break that ungodly silence, lifting our spirits and bolstering our shaken morale."

(Sands, 1998: 46)

5.17 To see the Hunger Strike as purely an emotional event, a rage against British Imperialism, would overlook the vast rational organisation that was part of the struggle: the timing, for example, of who went on hunger strike and when, was strictly planned to maximise media and political impact; the hiding and transporting of information, the 'comms', smuggled inside bodies to coordinate external and internal activities required meticulous planning. Therefore, the hunger strike could be seen as being compliant with modernity standing in a tradition where there is self-sacrifice for high modernist ideals such as liberty as well an example of Durkheim's homo-duplex, rational action underpinned by emotional commitment.

\section{Concluding comments}

6.1 In the context of Northern Ireland, Bobby Sands and the other hunger strikers using their bodies as weapons effected a considerable change, the main impact being to accelerate the Republican movement into emphasising the ballot box over the bomb (English, 2003). Sands' victory in the Fermanagh/ South Tyrone by-election alerted the Republican movement to the possibilities and opportunities that political power and influence could bring, an avenue that they had been wary of pursuing in the past. ${ }^{[2]}$ Importantly though, as we have seen, the hunger strikers actions were not prompted by a mythic past or the narratives of self sacrifice immanent within Catholicism but out of cold hard political reality. That reality meaning that they had to turn to the one resource they had available to them: their embodiment.

6.2 This wilful agentic embodiment provides an example of how, and why, embodiment can exert 'upstream' influences on society leading both to resistance and engagement with social structures. It also provides an example, previously undertheorised within sociology of the body, of how embodiment figures in political situations, especially where violence and conflict are present. This exploration of the 'body-as-weapon' should provide a timely contribution both to sociology of the body and an understanding, given current global politics, of contemporary uses of the 'body-as-weapon'.

\section{Notes}

1 In the absence of primary interview data this paper draws on available documentary evidence. Both Scott (1990) and Prior (2003) have discussed the use of documents in social research. Documents are not to be regarded as static entities but rather as bound into the social world, capable of interweaving a variety of social, personal, official and unofficial biographies and narratives. One notable aspect of Republican prisoners is their output, written either during their time in prison or after being released. Thus there exists a documented archive that records the prisoners' experiences during the Hunger Strike or their later reflections on it. Personal records, such as diaries, can provide insights into the actions of particular individuals providing information that is not always accessible via the usual academic interview method. For instance, in the Sands' $(1998,2001)$ prison diaries and poems, we find the very intimate thoughts, representations and interpretations of the Hunger Strike as it unfolded, of a young man with fervent Republican ideals. One could legitimately question the partiality of the views he expresses given his explicit political beliefs. However, the purpose of this paper is to explore how marginalised political groups use embodiment and bodies to resist and it is their agency and representations that are critical in meeting that task. The same consideration is equally applicable to the other sources deployed here, including a qualitatively rich mixture of autobiography, academic study and political agitation and analysis. Examples include the work of McKeown (2001) which encompasses his post-doctoral research in addition to recollecting his own experiences as a hunger striker. Campbell et al.'s (1994) collected volume is much more political in orientation, but contains interviews with 28 Republican prisoners involved in H-block protests between 1976 and 1981. The only documentary source not written by Republican (ex-) prisoner is that of the anthropologist Feldman (1991). To summarise then, the selected documents and texts offer access to the recorded accounts of how surviving prisoners interpreted the meaning of the Hunger Strike.

2 Though as English, (2003) and Taylor (1998) note there have been times when the Republican leadership have communicated in secret with the British authorities from the early 1970 s onwards.

\section{Acknowledgements}

I would like to thank Phil Sutton for his comments on various drafts of this paper; those who attended my presentation at the 2004 BSA annual conference; and the anonymous referees who guided this paper to publication. Special mention should also be made of the encouragement and support provided by Johnny and Marie-Louise Muir, Rory Lynch and June Wells. 


\section{References}

ANDERSON, B. (1991) Imagined Communities, London: Verso.

ALLEN, K. (1990) The Politics of James Connolly. London: Pluto Press.

ANDERSON, J. \& Shuttleworth I. (1998) Sectraian demography, territoriality and political development in Northern Ireland. Political Geography 17 (2): 187-208.

BAUMAN, Z. (1992) Survival as social construct. Theory, Culture and Society. 9(1): 1-36.

BERESFORD, D. (1994) Ten Men Dead: the Story of the 1981 Hunger Strike. London: Harper Collins.

BOURDIEU, P. (1984) Distinction: A Social Critique of the Judgement of Taste. London: Routledge.

BURKITT, I. (1999) Bodies of Thought: Embodiment, Identity and Modernity. London: Sage.

CAMPBELL, B., McKeown, L. \& O'Hagan, F. (1994) Nor Meekly Serve my Time: the H-Block Struggle 1976 - 1981. Belfast: Beyond The Pale.

CLARKE, L. (1987) Broadening the Battlefield: the H-Blocks and the Rise of Sinn Féin. Dublin: Gill and MacMillan.

COLLINS, R. (1998) 'The Durkheimian tradition in conflict sociology', in Alexander, J.C. Durkheimian Sociology: Cultural Studies. London: Routledge.

COOGAN, T. P. (2002) On the Blanket: the Inside Story of the IRA Prisoners' "Dirty" Protest. New York: Palgrave MacMillan.

CROSSLEY, N. (1995) 'Merleau-Ponty, the elusive body and carnal sociology. Body and Society 1(1): 4363.

COULTER, C. (1999) Contemporary Northern Irish Society: an Introduction. London: Pluto Press.

DANGERFIELD, G. (1997 [1935]) The Strange Death of Liberal England. London: Serif.

DE PAOR, L. (1970) Divided Ulster. Harmondsworth: Penguin.

DURKHEIM, E. (1968) The Rules of Sociological Method . New York: The Free Press.

DURKHEIM, E. (1973) On Morality and Society. Chicago: University of Chicago.

ELIAS, N. (2000) The Civilising Process. Oxford: Blackwell.

ENGLISH, R. (2003) Armed Struggle: a History of the IRA. London: MacMillan.

FELDMAN, A. (1991) Formations of Violence: the Narrative of the Body and Political Terror in Northern Ireland. Chicago: University of Chicago.

FEATHERSTONE, M (1991) The body in comsumer culture, in M. Featherstone, M. Hepworth and B.S. Turner (eds) The Body: Social Process and Cultural Theory. London: Sage.

GIDDENS, A. (1991) Modernity and Self-identity: Self and Society in the Late Modern Age . London: Polity.

GOFFMAN, E. (1968) Stigma: Notes on the Management of Spoiled Identity . Harmondsworth: Penguin.

GRAHAM, B. \& Shirlow P. (2002) The battle of the Somme in Ulster memory and identity. Political Geography 21: 881-904.

GROSZ, E. (1994) Volatile Bodies: Toward a Corporeal Feminism. Bloomingtion: University of Indiana Press.

HARAWAY, D. (1991) Simians, Cyborgs and Women. London: Free Association Books.

HUTTON, R. (1993) The Pagan Religions of the Ancient British Isles: Their Nature and Their Legacy. Oxford: Blackwell. 
HUTTON, R. (1994) The Rise and Fall of Merry England: the Ritual Year 1400 - 1700. Oxford: Oxford University Press.

INGLIS, D. \& Holmes, M. (2000) Defecation, temporal strategies and the dilemmas of modernity. Time \& Society 9(2/3): 223-245.

INGLIS, D. (2002) Dirt and denigration: the faecal imagery and rhetorics of abuse. Postcolonial Studies 5(2): 207-221.

INGLIS, T. (2003) Catholic church, religious capital and symbolic domination, in Boss, M. \& Maher, E. (eds.) Engaging Modernity: Readings of Irish Politics, Culture and Literature at the Turn of the Century . Dublin: Veritas.

MCCANN, E. (1980) War and an Irish Town. Worcester: Pluto Press.

MCKEOWN, L. (2001) Out of Time: Irish Republican Prisoners: Lon Kesh 1972-2000. Belfast: Beyond the Pale.

MERLEAU-PONTY (2002 [1945]) Phenomenology of Perception . London: Routledge.

MULCAHY, A. (1995) Cliams-making and the construction of legitimacy: press coverage of the 1981 Northern Irish Hunger Strike. Social Problems (42) 4:449 -467.

O'MALLEY, P. (1990) Biting at the Grave: the Irish Hunger Strikes and the Politics of Despair. Boston: Beacon Press.

O'NEIL, D.J. (1984) The cult of self-sacrifice: the Irish experience. Social Studies 24 (4): 83-105.

PRIOR, L. (2003) Using Documents in Social Research. London: Sage.

ROLSTON, B.(1991) Politics and Painting: Murals and Conflict in Northern Ireland. Rutherford: Associated University Press.

SANDS, B. (1998) Writings from Prison. Dublin: Mercier Press.

SANDS B. (2001) One Day in my Life. Dublin: Mercier Press.

SCOTT, J. (1990) A Matter of Record . Cambridge: Polity.

SHILLING, C. (1993) The Body and Social Theory. London: Sage.

SHILLING, C. (1997) Emotions, embodiment and the sensation of society. Sociological Review 45: 195219.

SHILLING, C. (1999) Towards an embodied understanding of the structure/ agency relationship. British Journal of Sociology 50 (4): 534-562.

SHILLING, C. (2001) Embodiment, experience and theory: in defence of the sociological tradition, Sociological Review 49(3) 327-344.

SHILLING, C. (2005) The Body in Culture, Technology and Society . London: Sage.

SIMMEL, G. (1950) The Sociology of Georg Simmel. London: The Free Press.

SMITH, A.D. (1986) The Ethnic Origins of Nations, Oxford: Blackwell.

SWEENEY, G. (1993) Irish hunger strikes and the cult of self-sacrifice. Journal of Contemporary History (28): $421-437$.

TAYLOR, P. (1998) The Provos: IRA and Sinn Fein. London: Bloomsbury.

TOOLIS, K. (1996) Rebel Hearts: Journey's Within the IRA's Soul. London: Picador.

TURNER B.S. (1984) The Body and Society . London: Sage.

TURNER B.S. (1996) The Body and Society . London: Sage.

TURNER, B.S. (1993) Max Weber: From History to Modernity. London: New York. 
TURNER, B.S. (2003) Biology, vulnerability and politics, in Williams, S.J., Birke, L., and Bendelow, G, (eds.) Debating Biology: Sociological Reflections on Health, Medicine and Biology. London: Routledge.

WILLIAMS, S.J. and Bendelow, G. (1998a) The Lived Body: Sociological Themes, Embodied Issues . London: Routledge

WILLIAMS, S.J. (1998b) 'Modernity and the emotions: corporeal reflections on the (ir)rational', Sociology, 32 (4): 747-69.

WILLIAMS, S. J. (2001) Emotion and Social Theory. London: Sage.

YUILL, C and Lewis, L. (2003) 'Interview with Mike Hepworth'. Medical Sociology News 29(2): 34-39.

YUILL, C. (2005) 'Marx: capitalism, alienation and health.' Social Theory and Health , 3(2): 126-143. 